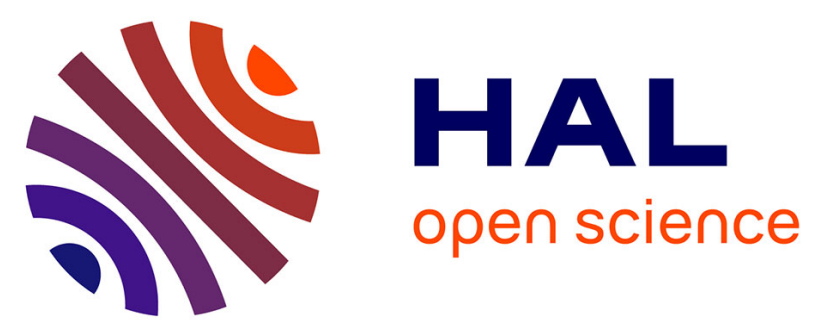

\title{
In Situ Microstructure Observation Of Steel Grades In The Semi-Solid State For Thixoforging Process By Using Confoncal Laser Scanning Microscopy
}

Guochao Gu, Raphaël Pesci, Eric Becker, Laurent Langlois, Régis Bigot

\section{To cite this version:}

Guochao Gu, Raphaël Pesci, Eric Becker, Laurent Langlois, Régis Bigot. In Situ Microstructure Observation Of Steel Grades In The Semi-Solid State For Thixoforging Process By Using Confoncal Laser Scanning Microscopy. Solid State Phenomena, 2015, 217-218, pp.15-22. 10.4028/www.scientific.net/SSP.217-218.15 . hal-01097545

\section{HAL Id: hal-01097545 https://hal.science/hal-01097545}

Submitted on 7 Jan 2015

HAL is a multi-disciplinary open access archive for the deposit and dissemination of scientific research documents, whether they are published or not. The documents may come from teaching and research institutions in France or abroad, or from public or private research centers.
L'archive ouverte pluridisciplinaire HAL, est destinée au dépôt et à la diffusion de documents scientifiques de niveau recherche, publiés ou non, émanant des établissements d'enseignement et de recherche français ou étrangers, des laboratoires publics ou privés. 


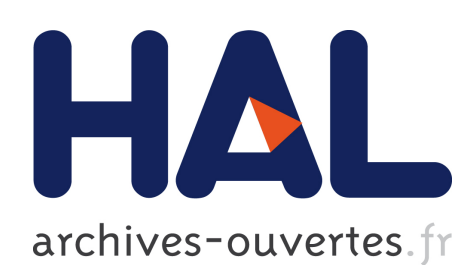

archives-ouvertes

\section{In Situ Microstructure Observation Of Steel Grades In The Semi-Solid State For Thixoforging Process By Using Confoncal Laser Scanning Microscopy}

Guochao GU, Raphaël Pesci, Eric Becker, Laurent LANGLOIS, Régis Bigot

\section{- To cite this version:}

Guochao GU, Raphaël Pesci, Eric Becker, Laurent LANGLOIS, Régis Bigot. In Situ Microstructure Observation Of Steel Grades In The Semi-Solid State For Thixoforging Process By Using Confoncal Laser Scanning Microscopy. Solid State Phenomena, 2015, 217-218, pp.1522. $<10.4028 /$ www.scientific.net/SSP.217-218.15>. <hal-01097545>

\section{HAL Id: hal-01097545 \\ https://hal.archives-ouvertes.fr/hal-01097545}

Submitted on 19 Dec 2014

HAL is a multi-disciplinary open access archive for the deposit and dissemination of scientific research documents, whether they are published or not. The documents may come from teaching and research institutions in France or abroad, or from public or private research centers.
L'archive ouverte pluridisciplinaire HAL, est destinée au dépôt et à la diffusion de documents scientifiques de niveau recherche, publiés ou non, émanant des établissements d'enseignement et de recherche français ou étrangers, des laboratoires publics ou privés. 


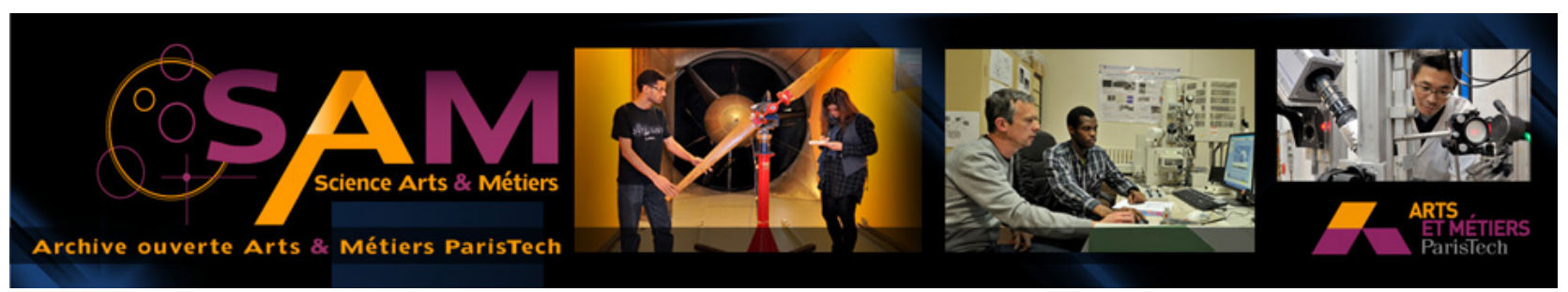

Science Arts \& Métiers (SAM)

is an open access repository that collects the work of Arts et Métiers ParisTech researchers and makes it freely available over the web where possible.

This is an author-deposited version published in: http://sam.ensam.eu Handle ID: .http://hdl.handle.net/10985/9128

\section{To cite this version :}

Guochao GU, Raphaël PESCI, Eric BECKER, Laurent LANGLOIS, Régis BIGOT - In Situ Microstructure Observation Of Steel Grades In The Semi-Solid State For Thixoforging Process By Using Confoncal Laser Scanning Microscopy - Solid State Phenomena - Vol. 217-218, p.15-22 2015 


\title{
In Situ Microstructure Observation Of Steel Grades In The Semi-Solid State For Thixoforging Process By Using Confoncal Laser Scanning Microscopy
}

\author{
Guochao Gu, a , Raphaël Pesci ${ }^{2, b}$, Eric Becker ${ }^{1, \mathrm{c}}$, Laurent Langlois ${ }^{1, \mathrm{~d}}$, \\ and Régis Bigot ${ }^{1, \mathrm{e}}$ \\ ${ }^{1}$ Laboratoire Conception Fabrication Commande (EA-4495), Arts et Métiers ParisTech \\ Metz, France \\ 2Laboratoire d'Etude des Microstructures et de Mécanique des Matériaux (LEM3), UMR CNRS \\ 7239, Arts et Métiers ParisTech CER Metz \\ Metz, France
}

aguochao.gu@gmail.com, braphael.pesci@ensam.eu, 'eric.becker@ensam.eu, daurent.langlois@ensam;eu, ${ }^{\mathrm{e}}$ regis.bigot@ensam.eu

Keywords: steel grades; semi-solid; microstructure evolution; CLSM

\begin{abstract}
The microstructure plays a crucial role for steel semi-solid forming process, and particularly for the steel thixoforging process, since it determines the thixotropic flow behavior of materials in the semi-solid state. Therefore, it is necessary to well understand the microstructure evolution during high speed heating and forming. Classically, it is investigated on a solid material quenched from semi-solid state by $2 \mathrm{D}$ characterization techniques. However, the semi-solid microstructure could probably not be preserved in the solid state by quenching due to complicated phase transformations or high diffusion rate of alloying elements during cooling, especially at low liquid fractions. In order to avoid this, a new in situ technique - high temperature Confocal Laser Scanning Microscopy (CLSM) - was developed and used for studying the microstructure evolution directly at high temperature.

The present study aims at providing an experimental investigation of the microstructure evolution on several steel grades (M2, 100Cr6 and C38LTT) during heating from the as-received state to the semi-solid state (heating rate: $\sim 200^{\circ} \mathrm{C} / \mathrm{min}$ ) and finally cooled to the solid state (cooling rate: $\sim 200^{\circ} \mathrm{C} / \mathrm{min}$ ).

It has been found that the temperature sensitivity of liquid fraction $(\Delta \mathrm{T} / \Delta \mathrm{fl})$ of these grades is much different. In addition, during cooling, there is a significant difference in diffusion rate of alloying elements between these grades. In M2, thanks to the high content of alloying elements and their low diffusion rate, the semi-solid temperature range is greater and its microstructure in the semi-solid state could be preserved by quenching process or even at a low cooling rate. On the contrary, the microstructure of other steel grades $100 \mathrm{Cr} 6$ and C38LTT in semi-solid state can only be revealed by CLSM at high temperature, because of the lower volume fraction of alloying elements and their high diffusion rate. It is very interesting to use high temperature CLSM to in situ investigate the microstructure evolution in the semi-solid state, especially at low liquid fraction. Since the microstructure of M2 in the semi-solid state can be reserved after cooling, it is possible to identify liquid area by the post-mortem examination. Therefore, the material flow behavior of thixoforged parts could be investigated.
\end{abstract}

\section{Introduction}

Taking advantage of the thixotropic properties, the metal slurries can be processed to produce complex parts with good mechanical properties by semi-solid forming. The thixotropic behavior is determined by the non-dendritic microstructure which consists of spheroidal grains in a liquid matrix. [1] Thixoforming is one of semi-solid forming route, in which a billet is heated until reaches the 
required semi-solid state with proper microstructure and then formed in the die. This technology has been applied in alloys with low melting temperature, such as magnesium and aluminum alloys [2]. Several collaborative activates on thixoforming were performed worldwide. The extensive effort was mainly concentrated on the industrialization of the steel thixoforming process to overcome the major obstacles. However, in these projects, the interested liquid fraction range was $(0.3<\mathrm{fl}<0.6)[3]$. In our study, we are interested in low liquid fractions $(0.1<\mathrm{fl}<0.3)$.

The required microstructure for semi-solid forming process can be obtained by several routes, which have been summarized in Ref. [4]. The recrystallization and partial melting (RAP) [5] and strain-induced melt-activated (SIMA) [6] are the more established solid state feedstock preparation routes. Recently, it was shown that tool steel X210CrW12 and M2 [7], stainless steel with a peritectic reaction [8], 100Cr6 [9] and C38 [10] could be subjected to a direct partial re-melting route, from their as-received conditions, to obtain a thixoformable microstructure. The volume fraction of solid phase and its distribution are important microstructure parameters that remain to be investigated, especially at low liquid fractions, because they crucially influence the rheological behavior [11] and therefore the flow behavior of a material during its forming [12]. Due to the high diffusion rate of elements and phase transformation behavior of steel during quenching, it is difficult to characterize the microstructure at low liquid fractions by conventional 2D quantitative metallography on quenched samples.

In situ techniques, such as synchrotron X-ray microtomography [13], Environmental Scanning Electron Microscopy (ESEM) [14] and Confocal Laser Scanning Microscope (CLSM) [15] have been developed and employed for real-time microstructure investigations.

In this study, C38LTT (low temperature for thixoforging), 100Cr6 and M2, were investigated considering the industrial applications and suitability of the thixoforging process, in particular to study the microstructure evolution during heating from the solid state to the semi-solid state by using in situ (CLSM) and ex situ techniques. In addition, a 3D semi-solid microstructure was reconstructed to show the solid skeleton and its distribution.

\section{Experimental procedure}

Materials. The materials used in this work were C38LTT, bearing steel 100Cr6 and high speed tool steel M2. C38LTT was specially manufactured for the thixoforming process by ASCOMETAL. The $100 \mathrm{Cr} 6$ was supplied after hot rolling process. After experiencing the hot rolling at a temperature of $\sim 1100{ }^{\circ} \mathrm{C}$, quenching and subsequently three times annealing for $1 \mathrm{~h}$ at $540{ }^{\circ} \mathrm{C}$, the M2 was received from the supplier ThyssenKrupp. The chemical composition of the starting materials is given in Table 1. C38LTT and 100Cr6 were investigated for the reason of industrial applications, while M2 was chosen for its high content of alloying elements for 3D characterizations.

Table 1. Chemical composition of the steel grades.

\begin{tabular}{|c|c|c|c|c|c|c|c|c|c|c|c|c|c|c|c|c|c|c|c|}
\hline & \multicolumn{19}{|c|}{ Chemical composition (wt 10 ${ }^{-3} \%$ ) } \\
\hline & $\mathbf{C}$ & $\mathbf{S i}$ & Mn & $\mathbf{S}$ & $\mathbf{P}$ & $\mathbf{N i}$ & $\mathrm{Cr}$ & Mo & $\mathrm{Cu}$ & Al & Sn & As & $\mathbf{B}^{*}$ & $\mathbf{V}$ & $\mathbf{T i}$ & Nb & $\mathrm{Ca}^{*}$ & $\mathbf{N}^{*}$ & $\mathbf{W}$ \\
\hline C38LTT & 399 & 596 & 1424 & 83 & 77 & 91 & 130 & 29 & 114 & 3 & 9 & 9 & 4 & 89 & 15 & 0 & 10 & & 0 \\
\hline $100 \mathrm{Cr} 6$ & 988 & 230 & 326 & 6 & 7 & 210 & 1428 & 82 & 194 & 31 & 13 & 10 & 2 & 4 & 3 & 1 & 2 & 109 & 0 \\
\hline M2 & 850 & 35 & 250 & $\leq 40$ & $\leq 40$ & 200 & 4100 & 5000 & 100 & & & & & 1900 & & & & & 6400 \\
\hline
\end{tabular}

Differential Scanning Calorimetry (DSC) measurements. DSC analyses were performed to estimate solidus and liquidus temperatures and the liquid fraction as a function of temperature of these materials. The measurement was performed in ASCOMETAL CREAS [12] for the C38LTT and $100 \mathrm{Cr} 6$ with heating rate of $20^{\circ} \mathrm{C} / \mathrm{min}$. M2 was tested by using a NETZSCH $404 \mathrm{C}$ Pegasus ${ }^{\circledR}$ at the heating rate of $20^{\circ} \mathrm{C} / \mathrm{min}$. Samples $(\varnothing 3 \mathrm{~mm} * 1.5 \mathrm{~mm})$ were machined from several billets in various positions in order to minimize the possibility of getting non-representative results due to possible variations of local composition caused by the segregation in longitudinal direction. Alumina with the same weight as the sample was used as a reference and Argon was applied during heating in order to prevent oxidation. 
In situ microstructure observation by Confocal Laser Scanning Microscopy (CLSM). A Lasertec $^{\text {TM }}$ 1LM21H-SVF17SP CLSM combined with a heating stage was used to perform the in situ investigations of microstructure evolution at high temperature. The sample $(\varnothing 5 * 3 \mathrm{~mm})$ was heated in a high purity argon atmosphere. In addition, titanium foils were placed near the sample surface to consume the oxygen during heating. Thus the oxidation phenomenon could be avoided. During the real-time investigations, various material samples experienced similar heating route but different maximum temperature according to the DSC results: $1450^{\circ} \mathrm{C}$ for $\mathrm{C} 38 \mathrm{LTT}, 1400^{\circ} \mathrm{C}$ for $100 \mathrm{Cr} 6$ and $1340^{\circ} \mathrm{C}$ for $\mathrm{M} 2$. The sample was heated at a rate of $50^{\circ} \mathrm{C} / \mathrm{min}$ from room temperature to $300^{\circ} \mathrm{C}$ with a $50 \mathrm{~s}$ holding time at $300^{\circ} \mathrm{C}$; and then at $200^{\circ} \mathrm{C} / \mathrm{min}$ to the maximum temperature without holding time. It was then cooled at $200^{\circ} \mathrm{C} / \mathrm{min}$ to room temperature. The heating stage was calibrated, showing that temperature difference between the reading temperature and the real temperature did not exceed $\pm 15^{\circ} \mathrm{C}$. Before the investigations, all samples were polished down to $1 \mu \mathrm{m}$ and etched to reveal the microstructure as well as adjust the focus and the magnification of the CLSM. After in situ ivestigations, the samples were prepared and observed at room temperature by optical microscopes and Scanning Electron Microscope (SEM).

Image analyses. In order to study the microstructure in the semi-solid state, billets with a diameter of $38 \mathrm{~mm}$ was partially induction heated. After quenching, the billets were subsequently ground, polished and etched using Nital $2 \%$ to reveal their microstructures. Microstructure observation and analysis were conducted by using an optical microscope and a JEOL 7001FLV SEM equipped with an EDS system. In addition, a 3D microstructure was constructed to show the solid skeleton and the liquid distribution.

\section{Results and discussions}
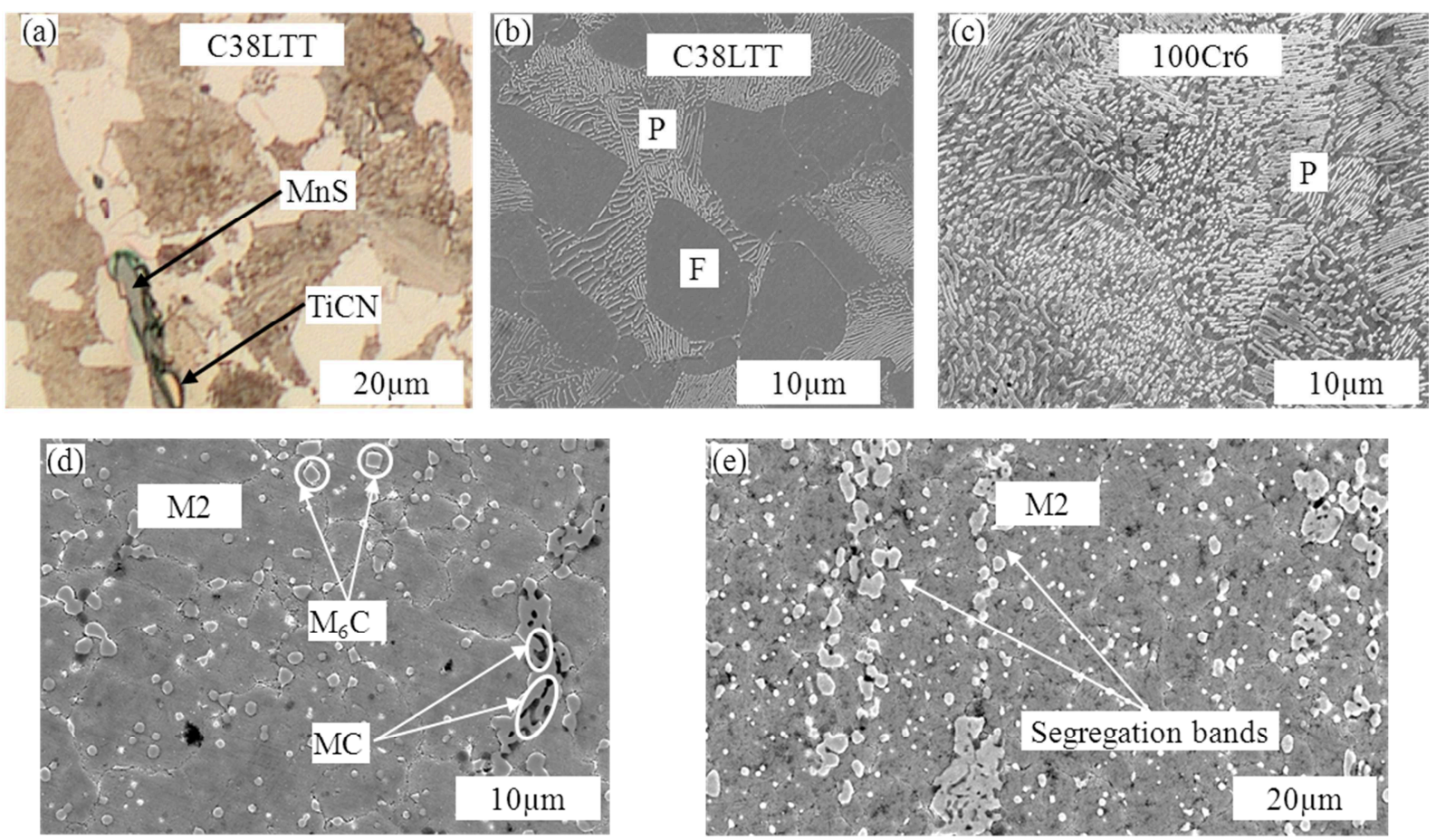

Fig. 1. Micrographs of as-received samples. C38LTT in (a) longitudinal direction (optical) and (b) transversal direction (SEM); 100Cr6 in (c) transversal direction; M2 in (d) transversal direction (SEM) and (e) longitudinal direction (SEM). P: pearlite; F: ferrite.

Starting materials. As shown in Fig. 1, the microstructure on transversal and longitudinal sections of materials were obtained by optical microscope and SEM. In addition, the inclusions of the materials were identified by EDS analyses. The results showed that the ferritic pearlitic steel C38LTT contained $\mathrm{MnS}$ and TiCN inclusions (Fig. 1a); 100Cr6 steel showed a pearlitic microstructure (Fig. 1c). As for the as-received M2 steel, the SEM-EDS observation found whiter carbides $\left(\mathrm{M}_{6} \mathrm{C}\right.$-type 
carbides which are rich in tungsten and molybdenum) and darker ones (MC-type carbides which are rich in vanadium, tungsten and molybdenum) (Fig. 1d and e). Moreover, the segregation banding along the longitudinal direction of the materials were also observed, which is related to the rolling process during manufacturing route. By using mean lineal intercept image analyses method, the average grain size of the materials is similar $\sim 10 \mu \mathrm{m}$.

Liquid fraction curve. Liquid fraction curves as a function of temperature obtained from DSC tests for the steel grades are shown in Fig. 2. It can be observed from these curves that the special manufactured C38LTT has a narrow semi-solid interval $\left(\sim 100^{\circ} \mathrm{C}\right)$ for the heating rate of $20^{\circ} \mathrm{C} / \mathrm{min}$, while M2 and $100 \mathrm{Cr} 6$ show larger semi-solid intervals $\left(\sim 190^{\circ} \mathrm{C}\right.$ and $160^{\circ} \mathrm{C}$, respectively). Additionally, the solidus temperature varies with alloying elements contents: $\sim 1410^{\circ} \mathrm{C}$ for C38LTT, $1330^{\circ} \mathrm{C}$ for $100 \mathrm{Cr} 6$ and $\sim 1250^{\circ} \mathrm{C}$ for M2. Moreover, the liquid fraction curve of M2 exhibits the complex melting behavior of $\mathrm{M} 2$ which may be caused by the dissolution of the carbides (MC and $\mathrm{M}_{6} \mathrm{C}$ ). Considering the DSC results, the materials (C38LTT, 100Cr6 and M2) were investigated in the liquid fraction range between $10 \%$ and $30 \%$, which corresponds to the temperature interval of $\left(\sim 1420^{\circ} \mathrm{C}-\sim 1460^{\circ} \mathrm{C}\right)$ for $\mathrm{C} 38 \mathrm{LTT},\left(\sim 1370^{\circ} \mathrm{C}-\sim 1400^{\circ} \mathrm{C}\right)$ for $100 \mathrm{Cr} 6$ and $\left(\sim 1250^{\circ} \mathrm{C}-\sim 134^{\circ} \mathrm{C}\right)$.

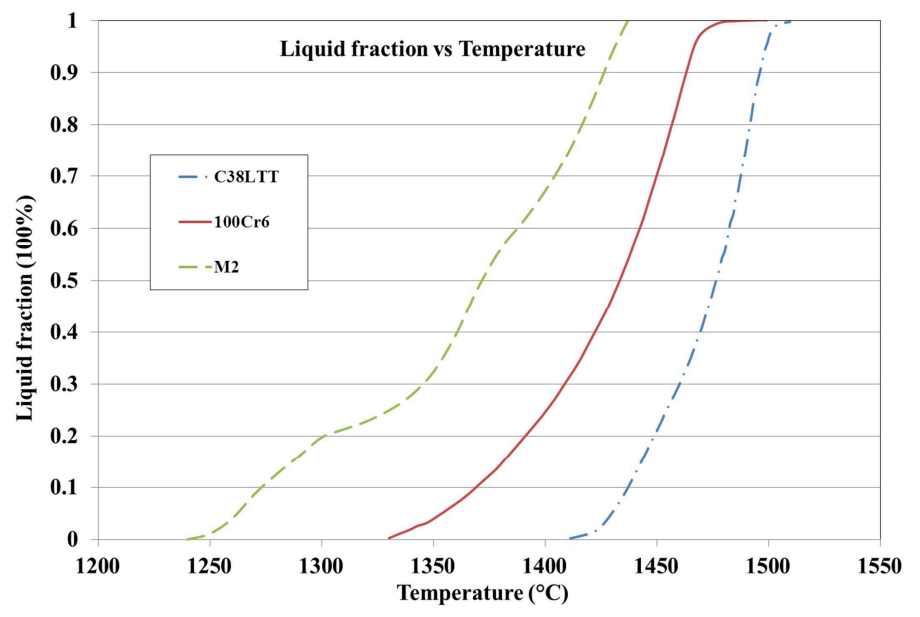

Fig. 2. Liquid fraction as a function of temperature obtained by $\operatorname{DSC}\left(20^{\circ} \mathrm{C} / \mathrm{min}\right)$.

Metallography and image analyses. In order to study the microstructure evolution during heating, the materials were investigated by quenching experiments and in situ CLSM tests.

Quenching experiments were carried out on the steel grades at their temperature ranges. Fig. 3 shows the microstructure of the steel grades quenched from the semi-solid state. For C38LTT and 100Cr6, martensitic structure was observed with barely evidence of former liquid phase after quenching (Fig. $3 \mathrm{a}$ and b). It is thought that the diffusion rate of the alloying elements during quenching was very fast that the cooling rate could not preserve the microstructure in the semi-solid state. As a result, the former liquid zones can not be identified from the microstructure quenched from the semi-solid state to room temperature. In comparison, the structures with spheroidal grains surrounded by interconnected carbides were observed for M2 (Fig. 3 c). The new carbides was formed from the liquid phase since the liquid was rich in alloying elements at high temperature.

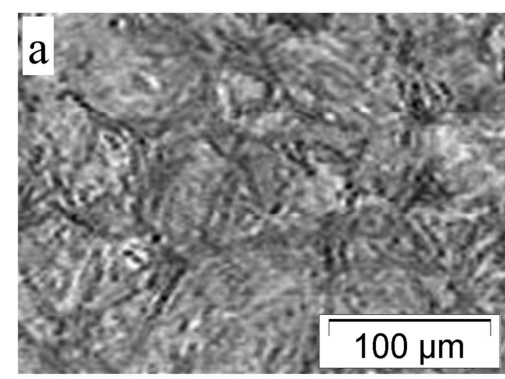

a.C38LTT at $1430^{\circ} \mathrm{C}$

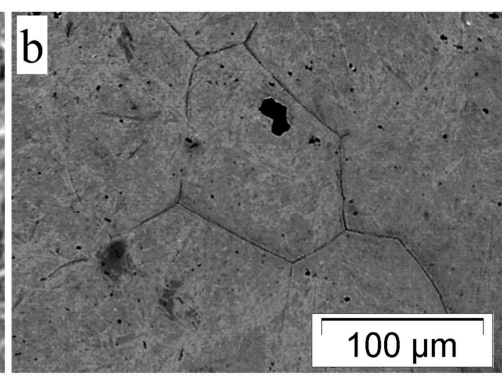

b. $100 \mathrm{Cr} 6$ at $1360^{\circ} \mathrm{C}$

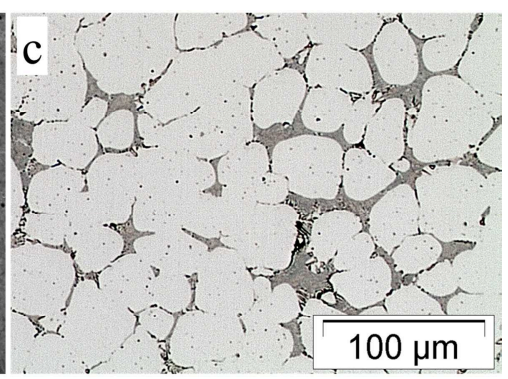

c. $\mathrm{M} 2$ at $1300^{\circ} \mathrm{C}$

Fig. 3. Microstructure of steel grades quenched from semi-solid state. 
In situ CLSM observations were first performed on C38LTT and 100Cr6 in order to study their microstructures at high temperature because it was difficult to retrieve their microstructures in the semi-solid state by the conventional quenching experiments. The microstructure evolution of M2 was also real-time observed by CLSM.

CLSM Micrographs of C38LTT at different temperatures were presented in Fig. 4. As shown in Fig. 4, the microstructure of C38LTT remained the ferritic and perlitic with the presence of small inclusions (Fig.4 (a)) until $\sim 740^{\circ} \mathrm{C}$, at which the austenization transformation occurred - the ferrite and perlite transformed to austenite. When entering the semi-solid zone, the liquid films appeared at the grain boundaries and the $\mathrm{MnS}$ inclusions were still remaining in the matrix and along the grain boundaries (Fig. 4 (b)). The liquid content increased with temperature. However, the liquid phase distribution was not uniform, as shown in Fig. 4 (c). The MnS inclusions changed a little even at higher temperature (Fig. 4 (c)). After cooling, the austenite grains and liquid phase transformed to perlite and ferrite. The CLSM samples were also investigated post mortem. By comparing the micrograph of CLSM sample with and without etching (Fig. 4 (e) and (f)), it was found that the former liquid phase corresponded to the ferrite grain boundaries, but not all the ferrite grain boundaries were the former liquid. Due to the insufficient cooling rate, the microstructure in the semi-solid state could not be identified by the microstructure at room temperature.
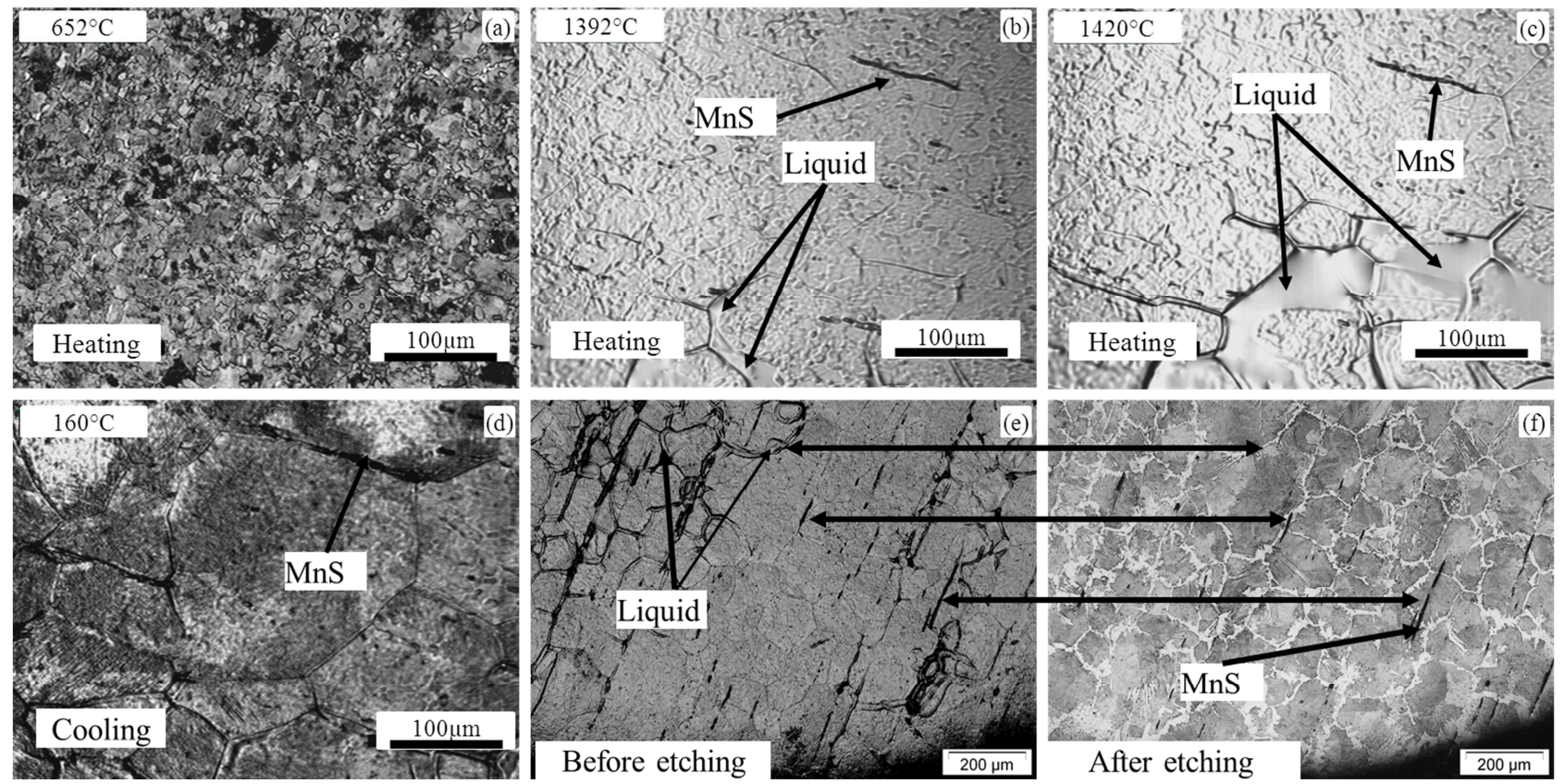

Fig. 4. (a)-(f) CLSM snapshots for the sequence of partial remelting of C38LTT during heating at $200^{\circ} \mathrm{C} / \mathrm{min}^{\circ}$ until $1420^{\circ} \mathrm{C}$ and the subsequent cooling. (e) Sample surface after cycle and (f) optical micrograph of the material shown in (e).

For $100 \mathrm{Cr} 6$, the microstructure evolution is shown in Fig. 5. After the austenization transformation (perlite to austenite) at $\sim 750^{\circ} \mathrm{C}$ during heating, the liquid appeared along the grain boundaries. There was a significant increase in liquid content with a small temperature increase $\left(\sim 20^{\circ} \mathrm{C}\right)$, as compared between Fig. 5 (b) and (c). During cooling, the austenite and liquid experienced several phase transformations and finally transformed to perlite, as shown in Fig. 5 (d). By comparing Fig. 5 (e) and (f), the pearlite was well observed by optical microscope on the CLSM investigated samples. However, it is difficult to correlate the final microstructure at room temperature with that in the semi-solid state.

For M2, the microstructure with small grain size and isolated carbides before reaching the austenization temperature $\left(\sim 880^{\circ} \mathrm{C}\right)$ was observed as shown in Fig. 6 (a). When reaching the austenization temperature, the alloying elements started diffusing into austenite (Fig. 6 (c)). However, the alloying elements content was too high to be totally dissolved. Furthermore, according to the phase diagram of $\mathrm{M} 2$, the $\mathrm{M}_{6} \mathrm{C}$ and $\mathrm{MC}$ carbides dissolve in the semi-solid range, but at 
different start dissolving temperature. The $\mathrm{MC}$ carbides dissolve first, while $\mathrm{M}_{6} \mathrm{C}$ dissolves later. Upon entering the semi-solid state, liquid appeared along the grain boundaries and the alloying elements diffused into the liquid phase and penetrated the grain boundaries. In addition, some small liquid droplets were observed inside the grains (Fig. 6 (d) and (e)) because of local small carbides particles. Kleiner et al. [16] described this phenomenon as self-blocking. During cooling, the liquid phase became new carbides since liquid was rich in alloying elements. It was also found that the new carbides have the same size and distribution as that of liquid phase in the semi-solid state (Fig. 6 (f)). After several solid-solid transformations (Fig. $6(\mathrm{~g})$ and $(\mathrm{h})$ ), the martensite matrix with inter-connected carbides were obtained confirmed by SEM observations (Fig. 6 (i)).

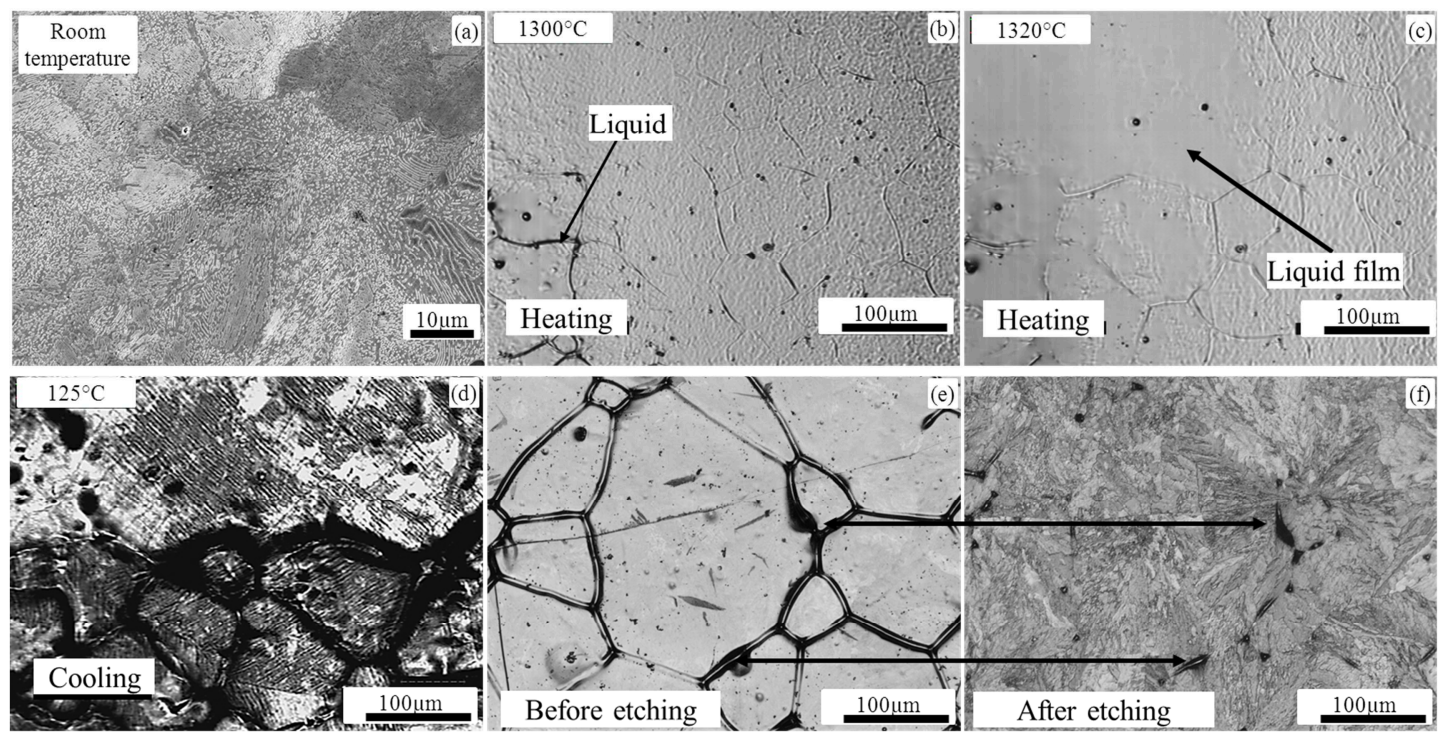

Fig. 5. (a). SEM micrograph of $100 \mathrm{Cr} 6$ in the as-received state. (b)-(d). HT-CLSM snapshots for the sequence of partial remelting of $100 \mathrm{Cr} 6$ during heating at $200^{\circ} \mathrm{C} / \mathrm{min}$ to a peak temperature of $1400^{\circ} \mathrm{C}$ and the subsequent cooling, (e) sample surface after cycling and (f) optical micrograph of the material shown in (e).

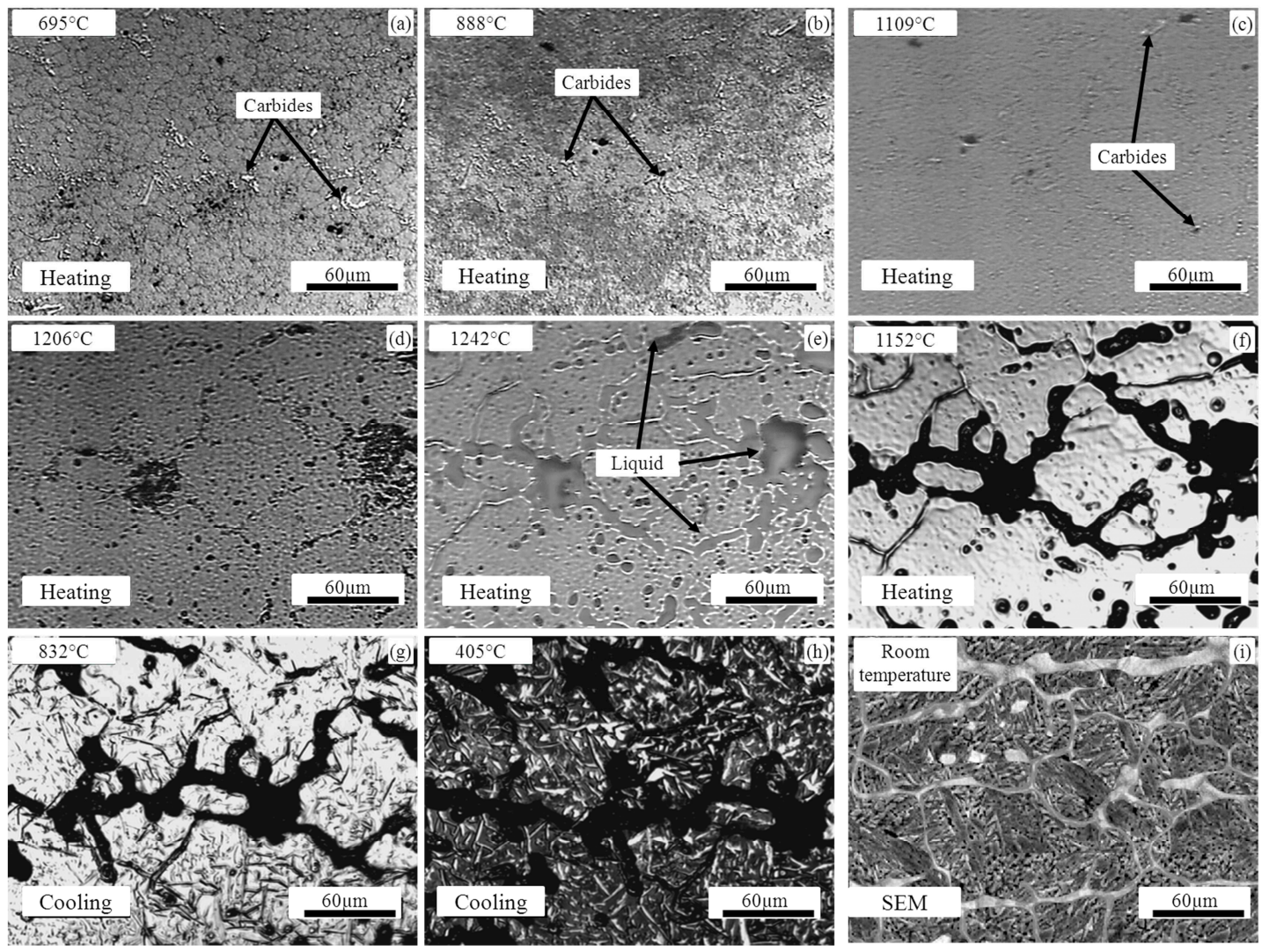

Fig. 6 . (a)-(i). HT-CLSM snapshots for the sequence of partial remelting of $M 2$ during heating at $200^{\circ} \mathrm{C} / \mathrm{min}$ to a peak temperature of $1250^{\circ} \mathrm{C}$ and the subsequent cooling. [15] 
As mentioned before, a proper microstructure with a suitable amount of liquid is necessary for successful thixoforming process. Generally, the liquid fraction as a function of temperature for steel grades depends on the chemical compositions and their distributions. Liquid fraction could be evaluated by DSC/DTA methods. For some steel grades, whose microstructure in the semi-solid state can be preserved by quenching, the liquid fraction could be determined by quantitative image analysis. However, as shown in Fig. 3, the microstructure of C38LTT and 100Cr6 at low liquid fraction could not be frozen by quenching. Thus the liquid fraction can not be evaluated by quenching experiments. Meanwhile, the microstructure evolution during heating is influenced by the manufacturing route, the distribution of chemical compositions as well as thermal history. For a given steel grade, the microstructure evolution could be investigated by CLSM. It could be seen that the liquid initiated in the grain boundaries during heating the grades. Although it was difficult to quantify the liquid fraction as a function of temperature due to the small field of view, it could be seen obviously that the liquid contents increased with temperature. However, the semi-solid range of C38LTT and 100Cr6 was relatively small as compared to that of M2. That means a higher precision should be required in temperature control for C38LTT and 100Cr6 during thixoforming. Considering the DSC results, the processing temperature ranges for C38LTT, $100 \mathrm{Cr} 6$ and M2 are $(\sim 1420-$ $\left.\sim 1450^{\circ} \mathrm{C}\right),\left(\sim 1360-\sim 1410^{\circ} \mathrm{C}\right)$ and $\left(\sim 1290-\sim 1340^{\circ} \mathrm{C}\right)$, respectively. Besides the liquid fraction, the morphology in the semi-solid state affects the thixoforging process significantly. Although the microstructure of the grades in the semi-solid state was not the classical one for thixoforging process, but is composed of equiaxed solid grains surrounded by liquid matrix. A structure with more spheroidal grains could be obtained with holding time. However, considering the industrial conditions, the long holding time was not used. By comparing the grain size of the steel grades in the semi-solid state, it was found that the average grain size of M2 was much smaller than that of C38LTT and 10Cr6, caused by the pinning ability of the carbides. From the CLSM results, it was found that the microstructure of M2 in the semi-solid could be preserved even by a low cooling rate. Meanwhile, it made the X-ray microtomography on M2 for 3D microstructure characterization possible because of its high content of alloying elements. A detail reconstruction of 3D stacks of M2 was explained in Ref. [15]. The solid skeleton of M2 in the semi-solid state could be observed as shown in Fig. 7. The solid skeleton is useful to support the sample and prevent it from collapsing prior to forming process.

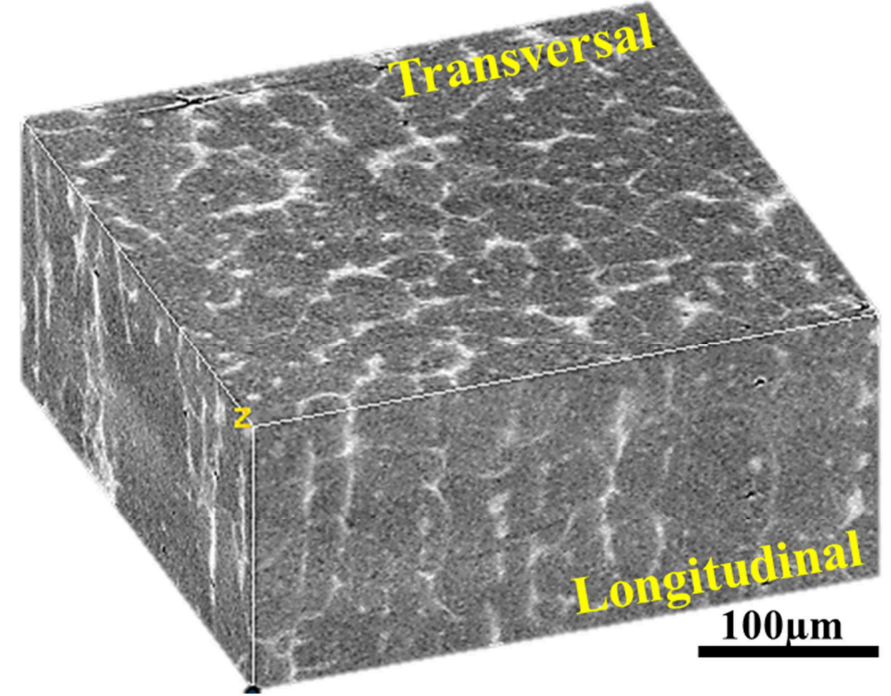

Fig. 7. 3D stack of M2 in the semi-solid state obtained by X-ray microtomography.

\section{Conclusions}

The microstructure evolution of C38LTT, $100 \mathrm{Cr} 6$ and M2 has been investigated by different techniques. The CLSM provides a possibility to directly investigate the microstructure at high temperature. Depending on the chemical composition and manufacturing process, the melting behavior of each grade was described. Combining the DSC, the CLSM results confirm that the 
temperature sensitivity of C38LTT and $100 \mathrm{Cr} 6$ is much higher which brings a difficulty in the temperature control for thixoforging. Beside 2D observation, the 3D microstructure of M2 was investigated. The solid skeleton was observed at low liquid fraction. It is used to support the billet and prevent it from collapsing prior to the thixoforging process.

\section{Acknowledgements}

The authors acknowledge the helpful discussions with Joris Van Dyck and Muxing Guo at the Catholic University of Leuven. They also warmly thank Marc Wary (Arts et Me 'tiers ParisTech CER Metz) for his technical support and advice.

\section{References}

[1] D. Spencer, R. Mehrabian, M.C. Flemings, Metallurgical and Materials Transactions B, 3 (1972) 1925-1932.

[2] D.H. Kirkwood, M. Suéry, P. Kapranos, H.V. Atkinson, K.P. Young, Semi-solid Processing of Alloys, Springer, 2010.

[3] H. Atkinson, A. Rassili, International Journal of Material Forming, 3 (2010) 791-795.

[4] G. Hirt, R. Kopp, in, Wiley-VCH Verlag GmbH \& Co. KGaA, Aachen, 2009, pp. 477.

[5] D.H. Kirkwood, C.M. Sellars, L.G. Elias Boyed, in, 1991.

[6] K.P. Young, C.P. Kyonka, J.A. Courtois, in, USA, 1982.

[7] M.Z. Omar, A. Alfan, J. Syarif, H.V. Atkinson, Journal of Materials Science, 46 (2011) 7679-7705.

[8] J. Li, S. Sugiyama, J. Yanagimoto, Y. Chen, G. Fan, Journal of Materials Processing Technology, 208 (2008) 165-170.

[9] R. Bülte, W. Bleck, Steel Research International, 75 (2004) 588-592.

[10] E. Becker, R. Bigot, L. Langlois, The International Journal of Advanced Manufacturing Technology, 48 (2010) 913-924.

[11] R. Bigot, V. Favier, C. Rouff, Journal of Materials Processing Technology, 160 (2005) 43-53.

[12] E. Becker, V. Favier, R. Bigot, P. Cezard, L. Langlois, Journal of Materials Processing Technology, 210 (2010) 1482-1492.

[13] N. Limodin, L. Salvo, M. Suéry, M. DiMichiel, Acta Materialia, 55 (2007) 3177-3191.

[14] A. Reichmann, P. Poelt, C. Brandl, B. Chernev, P. Wilhelm, Oxidation of Metals, 70 (2008) 257-266.

[15] G.C. Gu, R. Pesci, E. Becker, L. Langlois, R. Bigot, M.X. Guo, Acta Materialia, In press (2013).

[16] S. Kleiner, O. Beffort, P.J. Uggowitzer, Scripta Materialia, 51 (2004) 405-410. 